In airing Schröder's work I am completely convinced that neither Kerr, Currie, Wyllie, Hopwood, nor Levison had any knowledge of it at the time their early papers were published. It has also escaped Muller's historical researches.

Independent and unwitting rediscovery is quite common: its benefits include fresh minds, new points of view, confirmation by repetition, and, often, greatly advanced techniques. It is not an occasion for shame. The contributions of the Australian and Scottish schools to the understanding of cell death have been imaginative, enthusiastic, and manifold. Schröder would reel in amazement at what they have uncovered; yet perhaps felicitously, he has eliminated both schools from the claim to priority.

Muller would do well to study Schröder's paper, retrieve its incomplete reference, ${ }^{3}$ and perhaps reconsider his own views. Instead of inciting destructive rivalry, his historical inclinations might be employed more benevolently to promote a Robert Schröder Memorial Lecture at the nex major meeting on cell death. In suitable hands, the story of Schröder's simple, useful, outstandingly reliable observation might enrich, inspire, and even graciously redress, a debt long overdue.

STEWART FLETCHER

Al Zahra Hospital,

Consultant pathologist

PO Box 3499,

Sharjah,

United Arab Emirates

1 Muller HK. Genesis of apoptosis. BMF 1994;308:1441 (28 May.)

2 Schröder R. Uber des Verhalten der Uterusschleimhaut um die Zeit der Menstruation. Maratschrift des Geburshülte und Gynakologie 1914;39:3-21.

3 Dallenbach-Hellweg G. Histopathology of the endometrium. 2nd ed. New York: Springer, 1975.

4 Hopwood D, Levison DA. Atrophy and apoptosis in the cyclical human endometrium. $\mathcal{F}$ Pathol 1976;119:159-66.

5 Buttner. Arch f Gyn Bd 92.

\section{Nocturnal ambulatory blood pressure measurement}

\section{Authors' reply}

EDrToR,-If we have understood Shennan et als letter about our recent paper on ambulatory blood pressure during sleep ${ }^{2}$ correctly, then the main problem is that they have assumed that the orienting reflex which is activated during arousal from sleep is due to the same physiological mechanism as the "white coat effect" while the subject is awake. There is no evidence to support this, and the time courses of the two vascular responses are very different. In addition, Shennan et al suggest that the haemodynamic response to ambulatory blood pressure measurement during the day is less likely to habituate to repetition than the haemodynamic response to measurements during sleep. This is incorrect, since the autonomic effects of arousal from sleep do not habituate with repetition at all (see references 4,11 , and 12 in our original paper), while the "white coat effect" does.

What our paper does show is that ambulatory cuff measurements raise the sleeping blood pressure variably between recording machines and subjects. Therefore they do not measure undisturbed sleeping blood pressure, but a combination of sleeping blood pressure plus an arousal component whose influencing factors and relevance to vascular risk are not yet adequately understood. The severity of this arousal component may be an important vascular risk factor, but it should be seen for what it is and not confused with an attenuated fall in blood pressure overnight.

RJO DAVIES Senior registrar in respiratory medicin JR STRADLING

The Churchill Hospital,

Consultant in respiratory medicin

Headington,

Oxford OX3 7LJ
1 Shennan A, De Swiet M, Halligan A. Nocturnal ambulatory blood pressure measurement. $B M f$ 1994;308:1634. (18 June.) 2 Davies RJO, Jenkins N, Stradling JR. Effect of measuring ambulatory blood pressure on sleep and blood pressure during sleep. $B M \Im$ 1994;308:820-3.

\section{Periocular steroid ointments may cause ocular damage}

EDrToR,-Jeremy $M$ Butcher and colleagues point out the dangers of long term unsupervised use of topical steroid drops but only briefly refer to topical, periocular steroid ointments as a potential source of ocular damage. ${ }^{1}$ Several reports have implicated periocular steroid preparations in the genesis of raised intraocular pressure and glaucomatous damage ${ }^{2-4}$ as well as the formation of cataracts." Although most of these cases have resulted from long term, periocular use of strong steroid ointments, Aggarwal et al reported a case of extensive visual loss after long term periocular use of $1 \%$ hydrocortisone ointment. ${ }^{4}$ This is particularly alarming as such a preparation is available from pharmacies without a prescription.

As Butcher and colleagues point out, the British National Formulary warns that topical steroid preparations should be used only under expert supervision. It should be made clear that the warning applies to both steroid drops and periocular ointments. Pharmacists dispensing $1 \%$ hydrocortisone ointment over the counter to unsupervised patients should warn them not to use the preparation periocularly for more than two weeks. Registrar R F J LOBO Clinical assistant D J BRAZIER Department of Ophthalmology, University College London Hospitals, London WC1F 6AU

1 Butcher JM, Austin M, McGalliard J, Bourke RD. Bilateral cataracts and glaucoma induced by long term use of steroid eye cataracts and glaucoma induced by
drops. $B M 7$ 1994;309:43. (2 July.)

2 Nielsen N, Sorensen PN. Glaucoma induced by application of corticosteroids to the periorbital region. Arch Dermatol 1978; 114:953-4.

3 Vie R. Glaucoma and amaurosis associated with long term application of topical corticosteroids to the eyelids. Acta Derm Venereol (Stockh) 1980;60:541-2.

Aggarwal RK, Potamitis T, Chong NHV, Guarro M, Shah P, Keterpal S. Extensive visual loss with topical facial steroids. Eye 1993;7:664-6.

5 Costagliola C, Cata-Giovannelli B, Piccirillo A, Delfino $M$. Cataracts associated with long term topical steroids. $\mathrm{Br} F$ Dermatol 1989;120:472-3.

\section{Complementary medicine in Germany}

EDITOR,-In their overview of the diverse situation regarding complementary medicine in Europe Peter Fisher and Adam Ward mention the German "Heilpraktiker" (health practitioner) stating that these practitioners "have passed an examination in basic medical knowledge." This is misleading.

There is no mandatory training to become a Heilpraktiker, and, even though every candidate has to pass a test, the Heilpraktiker's qualifications are pitifully low..$^{24}$ The only guideline for the test is to "exclude danger to the health of the nation." If a candidate fails the test he or she can take it again, at the same place or elsewhere, as often as desired. Failure rates vary from 0 to $100 \%$, with an average of around $60 \%$. $^{3}$ Thus a thriving "examination tourism" has developed to those authorities with high average pass rates. ${ }^{3}$ The test may be oral or written, lasts from 20 minutes to five hours, and covers mostly legislation; essentially, candidates must know which procedures they are not legally allowed to perform. Medical knowledge is rarely included. ${ }^{3}$

A Heilpraktiker practises predominantly (but by no means solely) methods that are unlikely to cause direct harm (there is, however, much concern about indirect risks-that is, missed diagnoses and otherwise incompetent behaviour). While complementary practitioners in Britain usually specialise in one or two complementary treatments, Heilpraktiker normally use many or all such treatments as well as diagnostic techniques of unproved or disproved validity. Heilpraktiker may also give subcutaneous and intramuscular injections. Complications and deaths occur. ${ }^{5}$

In Britain the call for registration of and control over providers of complementary medicine is becoming louder. The Osteopaths' Bill and the proposed Chiropractors' Bill are important steps towards control over educational and professional standards. The example of the Heilpraktiker suggests that registration without proper training (which should mean not merely a minimal amount of knowledge but also the right sort of knowledge) will not lead to acceptable standards of safety Even an intrinsically safe remedy may become unsafe when not applied with competence. Thus professional competence is essential and must be considered when complementary medicine is discussed.

Centre for Complementary Health Studies,

E ERNST

University of Exeter,

Exeter EX4 4PU

1 Fisher P, Ward A. Complementary medicine in Europe. $B M g$ 1994;309:107-11. (9 July.)

2 Kuni H, Oepen J, Becker P. Der staatliche Qualifikationsauspruch an die Ausübung der Heilkunde. Arzt und Krankenhaus 1982;35:286-9.

3 Eberhart J, Püschel K. Sachkunde und Uberprufungspraxis be Heilpraktikern. Offentliches Gesundheitswesen 1988;50:579-83.

4 Lubbe R. Die Heilpraktikerüberprüfung 1980-1991 im Bereich des Regierungspräsidenten Detmold-Bestandsaufnahme und Analyse. Das Gesundheitswesen 1993;55:253-8.

5 Hildebrand E. Lehren an einem Oxontherapie-Todesfall. Medizinische Welt 1987;38:1228-31.

\section{Hopeful newspaper article was justified}

EDrToR,-John R Petrie argues that an article by me in the Times drawing attention to a new cancer drug that is undergoing phase III trials in 26 centres in Britain and elsewhere in Europe is an example of "sensational reporting by poorly informed journalists." Petrie is from Scotland; it is unfortunate that before writing his article he did not consult colleagues at Glasgow Royal Infirmary, Aberdeen Royal Infirmary, and Ninewells Hospital in Dundee, all of which hospitals are participating in the phase III study of lithium gammalinolenate in pancreatic cancer.

It is also a pity that the databases Petrie consulted during his literature search seem to have failed him. I can provide a list of more than 25 studies of lithium gammalinolenic acid in cancer, several of which are in well known publications such as the Fournal of the National Cancer Institute. A phase II trial of lithium gammalinolenate in pancreatic cancer has been conducted in 48 patients at Edinburgh Royal Infirmary and Addenbrooke's Hospital in Cambridge. Partial results from this study were presented at a meeting of the American Association for Cancer Research last May and at a joint conference on cancer held by the National Cancer Institute and the European Organisation for Research and Treatment of Cancer in Amsterdam in March. The results of this phase II study were summarised in an earlier article in the Times, to which I would happily have referred Petrie had he contacted me. 